\title{
EEF2 Gene
}

National Cancer Institute

\section{Source}

National Cancer Institute. EEF2 Gene. NCI Thesaurus. Code C38584.

This gene plays a role in nucleotide binding and protein biosynthesis. 